\title{
WeLLMANN LÁSZLÓ*
}

\section{KÉPESLAPOK, RAJZOK ÉS EGYÉB ÁBRÁZOLÁSOK AZ ELSŐ VILÁGHÁBORÚBÓL}

\author{
Kulcsszavak: első világháború, levelezés, háborús propaganda, ábrázolások
}

2014-ben az első világháború kitörésének 100 éves évfordulójára emlékeztünk. Európa számára a napóleoni háborúk után egy évszázados békeidőszak köszöntött be, amelyet aztán az 1914 és 1918 között zajló világégés tett semmissé. Az első világháború abban is újat hozott, hogy következtében térségünkben államok estek szét, területek cseréltek gazdát, évszázados dinasztiák vesztették el hatalmukat - bizonyos esetekben az uralkodóházak több tagja erőszakos halált halt-, megjelent a magyar kisebbség Közép-Kelet-Európa térképén, és véget ért az, amit öregjeink a boldog békeidőknek neveztek. Ez a történelmi esemény a nemzetközi diplomáciát, a nemzetközi politikát és politizálást is jelentősen átalakította. Hogy csak egy példával éljünk, a világban először került hatalomra a kommunizmus. Mint említettem, 2014 az emlékezés éve volt, kiállításokkal, konferenciákkal és egyéb rendezvényekkel. Magáról az első világháborúról ugyanakkor azért is fontos emlékezni, mert egyrészt a haditechnika fejlettsége az emberi veszteségeket hatalmasra duzzasztotta, másrészt pedig az orvostudomány számára is új lehetôségek, új kívánalmak jelentek meg. Nem szabad azt sem elfelejteni, hogy a világégés lezárása után milyen óriási problémát jelentett a harcvonalakról hazaérkezett katonák beintegrálása a civil életbe.

A 2014-ben megjelent cikkek kapcsán fontos kiemelni azokat, amelyek a hadipropagandával, a háború alatt készült képekkel foglalkoztak. Cikkünk is hasonló témát igyekszik bemutatni, nevezetesen olyan első világháborús leveleket, amelyek valamilyen rajzot, nyomtatott ábrát, képeslapot és ezekhez tartozó szövegeket tartalmaznak. Fontosnak tartjuk kiemelni azt, hogy az általunk kutatott és most bemutatásra kerülő anyag nem csak egyszerúen a háborús propagandára jellemző, hanem olyan ábrázolásokkal is találkoztunk, amelyek településeket illetve a fronton lévők és a hátország különböző vágyait, ábrándjait próbálják bemutatni. Kutatásunkat a Román Nemzeti Levéltárak Kolozs Megyei Osztályában végeztük, ahol egy Kelemen Lajos kezdeményezése és kitartó munkája során egybegyújtött és a hajdani Erdélyi Nemzeti Múzeum Levéltárába megőrzésre elhelyezett - több mint 30000 darabból álló, túlnyomórészt magyar, de német, román, cseh, lengyel, angol és héber nyelvú tábori lapokat, leveleket és fényképeket tartalmazó világháborús levélgyújteményt ôriznek. A több csoportra oszló gyújteményből az első 91 iratcsomót néztük át, melyekben az erdélyi vármegyékbeli településekre küldött levelek találhatók. Mivel most a történelmi Erdélyről beszélünk, a csoportban nem szerepelnek a Zilahra, Nagyváradra vagy Aradra küldött levelek. A 91 iratcsomó ugyanakkor nem jelenti azt sem, hogy tartalmuk 91 különböző településre küldött levélanya-

* Wellmann László (1981), dr., történész, a Babeş-Bolyai Tudományegyetem Levéltárának alkalmazottja. E-mail: laszlowellmann@gmail.com. 
got tartalmaz, ugyanis léteznek olyan helységek - például Kolozsvár, Várfalva vagy Torockó -, amelyek esetében a levelek nagy száma miatt több iratcsomót is létesítettek. ${ }^{1}$ A kutatás során az is nyilvánvalóvá vált, hogy, még ha egy-egy iratcsomó több száz levelet is tartalmaz, közöttük legtöbbször kevés rajzot, képet és ábrát találunk.

Az átvizsgált anyagot több csoportra osztottuk: 1. különböző települések utcáit, tereit, domborzati formáit és természeti képződményeit ábrázoló képeslapok; 2. a katonák mindennapjait, ábrándjait, vágyait, a hadi eseményeket és az otthon maradottakat bemutató képeslapok; 3. akvarellek és karcolatok; 4. reklámokat is tartalmazó képeslapok; 5. imádságokat és buzdító üzeneteket tartalmazó képeslapok; 6. rajzokat tartalmazó tábori levelezőlapok; 7. a központi hatalmak és szövetségeseik uralkodóinak képeit tartalmazó, szöveges vagy anélküli levelezőlapok; 8. a központi hatalmak szövetséges hadseregeiben szolgáló fótisztek mellképeit ábrázoló levelezőlapok; 9. térképeket tartalmazó tábori levelezőlapok; 10. fényképek; 11. karikatúrákat tartalmazó levelezőlapok.

A továbbiakban kutatási eredményeinket, a jelen közlési lehetőségekhez igazítva, néhány példával szemléltetjük. Ami az első csoportba tartozó leveleket illeti, ezek korabeli képeslapok, amelyeket a katonák küldtek szeretteiknek. A képeslapokon Ausztria-Magyarország egyes városai, természeti és domborzati formái láthatóak. A többször szereplő települések közül megemlítjük Lemberget, Prágát, Budapestet, Szolnokot, Nagyváradot, Nagyszebent, Egert, Dornavátrát. ${ }^{2}$ A domborzati formák és természeti képződmények közül kiemelhetjük a Cibles-csúcsot, a kőrösmezői Tisza-forrást vagy a Großglockner-csúcsot. ${ }^{3}$

A második csoportba tartozó levelekkel kapcsolatban több olyan példánk is van, melyek a katona mindennapjait mutatják be. Megemlítünk egy katonai étlapot, melynek felirata: Hétfö: Savanyú lencse. (Gyomorbaj.)/Kedd: Borjúpaprikás. (Katona bácsi kedvencze.)/Szerda: Krumpli csuszpájz. (Hascsikarás.)/Csütörtök: Lencse füstölt hússal. (Nagy takaritás.)/Péntek: Tejben rizskása. (Galiba a nyeldeklöben.)/Szombat: Krum[p?]lis gombócz. (Nem is olyan rossz.)/Vasárnap: Sertés karajtöltött káposztával. (A katona ebböl nagyokat fal.) ${ }^{4}$ A napi fogások után egy-egy egyenruhás katona arckifejezése minősíti az étkeket. A kép jobb felső részén tábori konyhai teamérést látunk, míg az alsó részén megterített asztalnál ülő, víg kedélyủ katona szól az ôt étellel kiszolgáló asszonyhoz, a részlet felirata: Este: Borral-csókkal, pecsenyével az idó is hamar mén el. ${ }^{5}$ (1. ábra) Következő példánk egy 1915. novemberi képeslap, amelyen egy csoport vidám

1 A Kolozsvárra küldött levelek két iratcsomóban vannak, számuk meghaladja a 800-at, Várfalvára több mint 1500 levél van címezve, ezek három iratcsomóban találhatók, Torockóra több mint 700 levelet küldtek, melyek szintén három iratcsomóban találhatók, Magyarsárosra 870 levél érkezett, melyeket ugyancsak két iratcsomóra osztottak. A felsorolásból kimaradtak azok a levelek, amelyeket például az említett helyekról származó hadifoglyok küldtek, mert azok két olyan külön iratcsomóban vannak, amelyek csak a hadifoglyok levelezését tartalmazzák.

2 A Román Nemzeti Levéltárak Kolozs Megyei Osztálya (Serviciul Judeţean Cluj al Arhivelor Naţionale ale României), Első világháborús levelek, 1914-1918 (Colecţia Scrisori din Primul Război Mondial, 1914-1918), 6. dosszié: 41; 7: 18, 79; 13: 5, 6; 25: 536; 30: 340; 32: 9; 38: 26; 47: 330, 336, 348; 58: 325; 59: 280, 281; 60: 109, 127, 128, 130, 133, 134, 137, 139, 141, 144, 148; 66 : 21; 80: 9,15 .

3 Uo. 16: 51; 21: 16; 24: 254.

4 Uo. 7: 146.

5 Uo. 
katona látható, egyikük a $A$ katonák tizparancsolata című papírt tartja a kezében: 1. Gondod legyen a fegyveredre, akár a babádra. 2. Ne irj haza, hogy elgörbült a „Schwarm-linia” és neked meg kell fizetned. 3. Mint öreg baka sob'se legyen sürgös a dolgod, mert a vén katona nem keleti express vonat. 4. A takarodó mindig a kaszárnyában találjon, még akkor is, ha nem szivesen hagyod abba babád ölelését. 5. Ne fuss a szoknyák után, de a lányoknak azért ne hagyj békét. 6 . Tiszteld szüleidet; a kapitány urat mint édes apádat, és az órmester urat, mint édesanyádat. 7. Az öreg bajtársaknak szolgálj dohánnyal és szedj el tölük minden munkát, ne hogy az öreg urak megeróltessék magukat. 8. Mikor az utolsó 100 napot temeted, ne hullass könnyet, hanem enyhitsd fájdalmadat egy kis jó itókával. 9. Ne idd le részeggé magad, nehogy a dutyiba kerülj és ott aludd át azt az idöt, mikor ismét szabad és civil lehetsz. 10. Ha véglegesen szabadságolnak, siess haza, nehogy a babád elcsípjen és ott tartson. ${ }^{6}$ (2. ábra)

A hosszú háború a családi viszonyokat is megváltoztathatta mind a házastársak, mind a szülők és az utódok között. Számos katona udvarolt már a háború előtt vagy aközben, így nem egy volt, akit a szíve vitt volna haza a harcvonalról. Máskor azonban a házasságok éppen a háború miatt mentek tönkre. Következő példáink az otthonától elszakadt katona szerettei utáni vágyakozásáról beszélnek. Egy 1915-ös levél vártán álló katonát ábrázol, aki a szeretőjével együtt töltött időről álmodozik. A lap szövege: Látomások./Hol van a szerencsém távoli szeretöm?/Csak az emlék marad meg/A csendes vártán vissza emlékszek/Az elvesztet[t] szép szerencsémre. $^{7}$ (3. ábra) Egy 1916-os levél szintén katonát ábrázol a szeretőjével: a levél alsó részén padon ülve egy kacéran mosolygó, kezében virágcsokrot tartó nő fordul el a felé hajló, jobb kezével őt ölelő katonától, fölöttük két madár van, egyik a fészkében ül, másik egy ágon. ${ }^{8}$ (4. ábra) Egy 1915-1916 fordulójáról származó üdvözlet áristomban lévő katonát ábrázol, míg a bajtársai kint sétálnak párjaikkal, szövege: Kaszárnya áristom./Ha gyönyörúen süt a nap/És szerelembe össze forr a világ/Egyedül és szomorúan/Otthon kell maradnom búsan. ${ }^{9}$ (5. ábra) Egy újabb levelezőlapon egyik felől, rózsával szegélyezett ovális keretben, a szeretőjétől felkantározott lova mellett búcsúzkodó huszárt látunk, míg másik felől egy harcmezei huszár-lovasrohamot, felirata: Bízzál Istenben. ${ }^{10}$ Ugyanez a lap német hosszabb felirattal is fennmaradt: In den Kampf!/Nun geht's zur Schlacht, das Roß ist gezäumt,/Herzlieb, jetzt wird geschieden!/Und was wir zwei so schön geträumt/Das schenk' uns Gott im Frieden. ${ }^{11}$ (6. ábra) Egy 1914 októberében keltezett levelezőlap ikerábrázolásainak egyikén egy harci felszerelésben lévő magyar katona, másikon egy gabonaföldön álló, kedvesét sirató leány látható, felirata: A hazáért egy dalom van;/Élet és halál!/Csak az egyet Isten adja/Minden hivének./A mását majd eldaloljuk/Ellenségének" ${ }^{12}$ (7. ábra)

A katonákat gyakran kerítette hatalmába a honvágy. Az érzelem plasztikus kifejeződését látjuk azon a levelezőlapon, amelyen három kucsmás katonát látunk a szabadban, egyikük

\footnotetext{
6 Uo. 47: 237.

7 Uo. 48: 73.

8 Uo. 318.

9 Uo. 32: 99.

10 Uo. 16: 54 .

11 Uo. 7: 21.

12 Uo. 58: 51.
} 
hátizsákján levelet ír, a másik komor arckifejezéssel figyeli őt, a harmadik pedig ôrt áll a háttérben, szövege: Ein Brief nach der Heimat. ${ }^{13}$ (8. ábra)

A négy éven át tartó háború idejéből számos karácsonyi, újévi vagy húsvéti üdvözlőlap is fennmaradt. Sok köztük a tipizált formájú, gyakran civileket ábrázoló lap, de akadnak szép számmal egyedi eseményeket megörökítő, katonákat ábrázoló ünnepi üdvözlőlapok is. Egy képeslapon például egy német és egy magyar katona fog kezet, felirata: 1915. Boldog ünnepeket! ${ }^{14}$ (9. ábra) Egy másik karácsonyi üdvözlőlapon őrt álló katonát látunk, felirata: Boldog Karácsonyi Ünnepeket! $1916 .{ }^{15}$ A rányomtatott hadosztályi megnevezés alapján az üdvözlőlap vélhetően a 38. Honvéd hadosztály katonái számára készülhetett. (10. ábra) A civileket ábrázoló üdvözlőlapok egyikén ünneplőbe öltözött fiatal férfi ékszert akaszt egy szintén ünneplőben lévő lány nyakába, mellettük karácsonyfa és ajándékok, a kép alján kézírással: Fröhliche Weihnachten!! ${ }^{16}$ (11. ábra) Az újévi üdvözlőlapok között is több érdekes példányt találtunk. Kiemeljük azt, amelyen egy társukat nyakukba emelő, vidám, mulatozó katonák kívánnak Boldog újévet. ${ }^{17} \mathrm{Az}$ ábrázolás propagandisztikus töltete vélhetően mindenki számára nyilvánvaló. (12.ábra) A húsvéti üdvözlőlapok közül megemlítjük azt, amely felső felén vélhetően otthonról kapott csomagjaikat bontó, közben levelet olvasó katonákat, alsó felén pedig egy padon ülő szomorú nőt és gyerekeit ábrázolja, felirata: Herzliche Ostergrüße. Húsvéti Üdvözlet. ${ }^{18}$ (13. ábra) Fontos hangsúlyozni, hogy az otthon maradt családtagok számára is hiányzott a harctérre távozott férj, apa, amint azt az alábbi német nyelvű húsvéti üdvözlőlap ki is fejezi. Ezen egy imádságra kulcsolt kézzel álló, karján húsvéti tojásokkal tele kis kosarat tartó gyermek és virágokkal szegélyezett, Mária és a kis Jézust ábrázoló oltár előtt fohászkodó anyja látható, a kép felső felén pedig a katonaruhában ábrázolt családapa, akinek arcára az otthonról kapott üdvözlet némi mosolyt csal. Az üdvözlet felirata: Gesegnete Ostern!/ Früblingsbot u[nd] Glockenklang/lenk zur Heimat deinen Blick,/Lieber guter Vater/kehre bald zurück! ${ }^{19}$ (14. ábra) Vannak vidámabb hangulatú üdvözletek is, melyek éppen a háború nyomasztó hangulatát igyekeztek feledtetni címzetteikkel. Egyik például kezében barkát és tojásos kosarat tartó leányt ábrázol, amint pórázon két-két kakast, illetőleg tyúkot vezet, felirata: Herzlichste Grüsse zum Osterfest? ${ }^{20}$ (15. ábra) Egy 1915 márciusában küldött lapon pedig egy kakas cilinderben beszélget egy ernyőt tartó tyúkkal, fölöttük vasúti hídon két tojás alakú vagonban csirkék utaznak. ${ }^{21}$

Példáink közül nem maradhatnak ki azon idealizált ábrázolások sem, amelyek a katonák harctéri tevékenységét vagy mindennapjait ábrázolják, kiemelve hol hősiességüket, hol az ellenfél gyenge pontjait. Az effajta propagandának fontos szerepe volt a hadviselő felek számára, ugyanis hozzájárult a csapatok harci szellemének fenntartásához, esetenként annak növe-

13 Uo. 19: 36 .

14 Uo. 6: 4.

15 Uo. 24: 68 .

16 Uo. $7: 155$.

17 Uo. 32: 8.

18 Uo. 16: 50 .

19 Uo. 32: 45.

20 Uo. $24: 30$.

21 Uo. 49: 93. Egy másik, hasonlóan pajkos üdvözlőlapon két ellentétes irányba tartó, egy összebogozódott rózsaszínű madzag két végét csőreikben tartó csirkét látunk. Uo. 50: 524. 
léséhez. A harci eseményeket megjelenítő kutatott ábrázolások között megtalálhatók mind a keleti front (legtöbb) eseményeit bemutató lapok, mind néhány olyan levél, amely az olasz, illetve a nyugati front eseményeit tárja elénk. Egy 1915 augusztusában kelt levelezőlap például három lobogót tartó győztes katonát ábrázol, felirata: Ein dreifaches Kaiserhoch der Verbündeten nach siegreichem Zurückdrängen der Russen. ${ }^{22}$ (16. ábra) Egy másik 1915-ös képeslapon erdőben harcoló katonák láthatók, felirata: Bajonettkampf der öster. ungar. Armee im Grodeker Wald. ${ }^{23}$ A levélen, ovális keretben, I. Ferenc József és a korona is látható. (17. ábra) Egy újabb levél szintén az oroszok elleni heves harcot ábrázolja, ezen már sebesültek is vannak, felirata: Kämpfe gegen die Russen. In den Rokitno-Sümpfen. ${ }^{24}$ (18. ábra) Nem hiányoznak a nyugati fronton szolgáló katonák hősiességét dicsőítő ábrázolások sem. 1915 márciusából való az a levél, amelyen egy kissé meghökkent arckifejezésű, enyhén előhajolt testtartású, jobb kezével tőrét vagy rohamkését előrántani készülő német katona jelenik meg ágyúk és egy emlékmü elöterében, felirata: Die Wacht am Rhein./So lang ein Tropfen Blut/Noch glüht,/Noch eine Faust den/Degen zieht,/Und noch ein Arm die/Büchse spannt,/Betritt kein Feind hier/deinen Strand! ${ }^{25} \mathrm{Az}$ olaszok elleni harcokról is találtunk képeslapokat. Egyiken például sziklás vidéken harcoló katonákat láthatunk, felirata: Krieg gegen Italien. Kämpfe unserer braven Truppen in Schnee und Eis. ${ }^{26}$ (19. ábra) Sokkal több azonban az olyan egyszerübb tábori levelezőlap, amelyen az Isonzo Armee 1915 feliratú, harcoló katonákat ábrázoló viszonylag kisméretű jelvény szerepel. ${ }^{27}$

A hadipropaganda számára fontos volt továbbá a szövetségesekkel való bajtársi, harctéri szolidaritás hangsúlyozása is. Erre a következő példák lehetnek szemléletesek. Egy harcra felsorakoztatott ágyúkkal tele harcmezőt mutató képen egy német és egy osztrák-magyar katona kezet fog, fölöttük pedig a két szövetséges uralkodó levélkoszorúval övezett portréja tűnik fel. ${ }^{28}$ (20. ábra) Egy másik képen szintén levélkoszorúval körülölelt német és osztrákmagyar lobogókat láthatunk. ${ }^{29}$ (21. ábra) Megemlítünk egy másik, számunkra érdekesnek tűnő, Viribus Unitis. Hazáért! Királyért! feliratú levelet is, melyen egy kéz német, osztrák és magyar zászlót tart. ${ }^{30} \mathrm{Az}$ osztrák zászló mérete kisebb a másik kettőnél, amit, kis fantáziával, akár a magyar katonai hősiesség fokozott szemléltetési szándékaként is értelmezhetünk. (22. ábra) Egy 1915-ös keltezésű levelezőlapon is az osztrák és a német vaskeresztes harci lobogó, illetve a magyar címerpajzs közös ábrázolása látható, felirata: Mit Gott für Kaiser und Reich ${ }^{\circledR 1}$ (23. ábra) A szövetséges bajtársiasság képi ábrázolása a harctéri események bemutatásánál is nyomon követhető, mint például az alábbi feliratú levelezőlap esetében: Kämpfe gegen die

22 Uo. 7: 20 .

23 Uo. 71.

24 Uo. 2: 457.

25 Uo. 60: 39.

26 Uo. 2: 458.

27 Uo. 41: 30, 62, 63, 65 .

28 Uo. 7: 154 .

29 Uo. 2: 617.

30 Uo. 326.

31 Uo. 6: 3; 10: 23. 
Russen. Ein russ. Kavallerie-Angriff wird durch gemeinsame, deutsche und österr.-ung. Truppen zurückgeworfen. ${ }^{32}$ (24. ábra)

Ami az ellenfelet illeti, a háborús propaganda ennek gyengéit igyekezett hangsúlyozni, hiszen, amint már jeleztük, a katonák harci szellemét ezzel is fokozni lehetett. Erre jó példa az a levél, melyen egy német és egy osztrák-magyar katona kergeti az ellenséget, felirata: Rette sich wer kann. Lerne laufen obne zu siegen. ${ }^{33}$ (25. ábra) Egy másik levél kozákokat üldöző német lovasokat ábrázol, felirata: Plündernde Kosaken von deutscher Kavallerie verfolgt. Hindenburg tábornok serege tönkreveri az oroszokat. ${ }^{34}$ (26. ábra)

Általános jelenség, hogy a háborúk során sok férfi, megalapozott ok vagy egyszerūen csak ügyeskedés folytán, a hátországban maradt. Emiatt feszültségek alakulhattak ki köztük és az éppen szabadságukat töltő, valódi harci tapasztalattal rendelkező katonák között. A két réteg nem éppen szívélyes viszonyát mutatja be az a levél, amelynek felirata: Itthon maradtak! Ezek közül választhatsz! A rajz négy alakot ábrázol: egy törpét, egy égimeszelőt, egy púpos, kopaszodó koravént és egy furcsa, beteges ábrázatú figurát. ${ }^{35}$ Feltételezzük, hogy az üzenet a szebbik nemnek is szólt, hangsúlyozva, hogy egy igazi férfinak háború idején harcvonalban a helye. (27. ábra)

Említésre méltó az illetékesek azon törekvése is, hogy a háború szörnyűségeiről az emberek figyelmét különböző kulturális műsorokkal tereljék el, melyek bevételeit aztán jótékonysági célokra fordíthatták. Ezen músorokra azonban a figyelmet hatékonyan csak jó reklámokkal lehetett ráirányítani. Erre példát egy olyan képeslap ad, amely egy többszörösen kitüntetett horvát atlétát ábrázol, és dicséri tetteit három - horvát, német és magyar - nyelvü felirattal: Mátijević Máriján! Horvátország legelsóbb és leghíresebb atlétája született Gráćácban. Az egykori katonai határörvidéken. A világ legerösebb embere tart magán $1.200 \mathrm{~kg}$ sulyt, fogaiban tart $450 \mathrm{~kg}$ sulyt. 500 korona jutalmat ad annak, aki képes bármily éles karddal kezét megsebezni avagy elvágni. Elöadásokat tart a Vörös Kereszt javára. ${ }^{36}$ (28. ábra)

A kutatott anyagban az akvarellek és karcolatok kis számban jelennek meg, ${ }^{37}$ továbbá két olyan képeslapra is rábukkantunk, amelyek a LYSOFORM nevú fertőtlenítő szert népszerüsítette. Az egyik, nem véletlenül, egy húszezer orosz hadifoglyot őrző, zsúfolt tábort ábrázol. $^{38}$ (29. ábrák)

Külön csoportot képeznek az imádságokat is tartalmazó képeslapok: egyik részük a hadsereg győzelméért szóltak, másik részük a csatatérre távozott családfő épséges hazatérésében reménykedő családtagok fohászait tartalmazták. Egy levél I. Ferenc Józsefet ábrázolja ima közben, felirata: Királyunk imája./Te ki szivekbe látsz,/Te tudod legjobban,/Nem akartam én így,/ Az én szivem mindig/Népeimért dobban./Magas Egek Ura!/Ne hagyj el most minket./Segitsd diadalra/E bösz viadalba,/Vitéz sereginket. ${ }^{39}$ Egy könyöklő angyalt ábrázoló másik levelezőlap

32 Uo. 25: 147.

33 Uo. 33: 21.

34 Uo. 24.

35 Uo. 30: 24 .

36 Uo. 48: 289.

37 Megemlíthetjük a pristinai nagymecset akvarelljét és egy 1916-os keltezésű levélen lévő konstantinápolyi mecsetet bemutató akvarellt. Uo. 48: 404; 59:200.

38 Uo. 2: 483, 566.

39 Uo. 2: 143. 
szintén háborús imádságot tartalmaz: Miatyánk Úristen/Kifenn vagy a menyben,/Vegyél minket kegyeidbe,/Segitsél a gyözelemre./Térden állva, esdve kérünk,/Legyél a mi hü vezérünk,/Élet-halál harcba megyünk,/Úristenünk legyél velünk!/Harci zászlónk fent lengetve,/Szüz Mária van rá festve,/Azzal megyünk a csatába,/Édes hazánk oltalmára. ${ }^{40}$ Találtunk olyan levelet is, amely egyik szövetséges uralkodó, a török szultán portréját és rövid, rímbe szedett imáját tartalmazza: Bosszút álló Al[l]ah,/Segits meg bennünket,/Hogy legyózhessük/Ellenségeinket. ${ }^{41}$ A családtagok imáját egy olyan képeslappal szemléltetjük, amelyen imádkozó nő és gyermek látható Szűz Mária képe előtt, imájuk pedig így hangzik: Unser Gebet!/Eine Kerze wir geloben/Dir Maria, bier zu Füßen,/Führst Du aus des Kampfes Toben/Heil den Vater uns zurück.12 (30. ábra)

Kis számban megőrződtek a katonák által készített rajzokat tartalmazó levelezőlapok is. Ezek gyakran virágot, puskagolyót, katonaportrét, repülőt, lányt ábrázolnak, többön virágmintával díszített betúket, esetleg stilizált iniciálékat is találunk. ${ }^{43}$

Szép számmal szerepelnek a gyüjteményben a központi hatalmak és szövetségeseinek uralkodóit ábrázoló levelezőlapok. A legtöbb I. Ferenc Józsefet és IV. Károlyt ábrázolja egymagában, de olyan is meglehetősen sok van, ahol I. Ferenc József II. Vilmos társaságában fordul elő, máskor harmadikként a török szultán is megjelenik. Ritkábban a három koronás fő mellett a bolgár cárt, Ferdinándot is feltüntetik. ${ }^{44}$ Ezek az ábrázolások megint csak azért voltak fontos hadipropaganda-anyag, mert a szövetséges seregek közötti bajtársiasságot hangsúlyozták. Néhány példával szemléltetjük a fentieket. Egy 1916-os levélen I. Ferenc József mellképét látjuk, Életünket és vérünket Hazánkért! Királyunkért! felirattal. ${ }^{45}$ Ugyancsak a császár medalionba foglalt mellképe látható egy másik, karácsonyi, színes levelezőlap-típuson is. ${ }^{46}$ (31. ábra) Újabb képeslapon négy katona ággal és virággal díszíti fel I. Ferenc József képét, felirata: Egy óhajunk, egy a vágyunk, Éltesse az Ég királyunk! ${ }^{47}$ (32. ábra) Egy 1914-es levél II. Vilmos és I. Ferenc József profilból, egymás mögött ábrázolt mellszobrainak fényképét ábrázolja, felirata: Egyesült Erốvel - Viribus Unitis. ${ }^{48}$ Egy 1915 májusában keltezett levél szintén a két uralkodó mellképét tartalmazza levélkoszorúban, felirata: Weltkrieg In Treue Fest. $1914{ }^{49}$ Fennmaradt olyan levelezőlap is, melyen II. Vilmos és I. Ferenc József levélkoszorúba foglalt arcképei mellett országaiknak lobogói is feltűnnek. ${ }^{50}$ (33. ábra) Említésre méltó továbbá az a levelezőlap is, mely egymás fölött ábrázolja I. Ferenc József, illetve II. Vilmos országzászlóik által szegélyezett portréját, melynek felirata: Wir halten fest und treu zusammen!

40 Uo. 24: 44.

41 Uo. 31: 510.

42 Uo. 50: 478.

43 Uo. 7: 148, 149; 50: 438; 58: 223; 85: 52.

44 A bolgár uralkodóról egy olyan képeslap is megőrződött a gyújteményben, ahol Ferdinánd cár mellképe alatt a következő felirat szerepel: A bolgár nemzet mellénk állott,/Ellenséggel szembe szállott. Uo. 24: 41.

45 Uo. 59: 130.

46 Uo. 7: 156.

47 Uo. 32: 94.

48 Uo. 8: 20, 21.

49 Uo. 85: 83.

50 Uo. 91: 52 . 
Hoch Kaiser Franz Josef! Heil Kaiser Wilhelm.151 Több olyan egyszerübb kivitelü lap van, mely a négy szövetséges uralkodóról készült metszetet tartalmaz, feliratuk: In treue fest vereint.$^{52}$ Ritkának számít viszont az a típus, amely II. Vilmos, I. Ferenc József és V. Mehmed portréját egy háromlevelű lóhere külön-külön levelein ábrázolja. ${ }^{53}$ (34. ábra)

Az uralkodókat ábrázoló képeslapok számához viszonyítva jóval kevesebb a fôtiszteket bemutatóké. Kutatásaink során csak az osztrák-magyar és a német hadsereg egyes tisztjeiről találtunk ábrázolásokat. Mindkét említett hadseregben az uralkodó dinasztiák tagjai is fôtiszti rangban szolgáltak. Egy levélen például Habsburg József főherceg mellképe található, az alábbi felirattal: Így szól ka[t]onáihoz Józseffóherceg/Csatára fel vitéz magyar sereg,/Mutassátok meg a világnak,/Hogy nincs párja a magyar katonának. ${ }^{54}$ Egy másik levelezőlapon, pajzson, lobogóval, nevének és katonai rangjának a feltüntetése mellett Habsburg Rainer fóherceg képe is megtalálható. ${ }^{55}$ Alig látható, rossz állapotban ugyan, de rábukkantunk egy olyan képeslapra is, amelyen a két uralkodó társaságában a német és az osztrák-magyar fótisztek is megjelennek, a feliratnak megfelelöen: Hötzendorfi Konrád vezérkari fönök, Vilmos trónörökös, Frigyes fóherceg, Károly Ferenc József trónörökösünk, I. Ferenc József, Hindenburg táborszernagy, II. Vilmos császár. ${ }^{56}$ Ezen csoportba tartozó példáinkat egy 1916-os levéllel zárjuk, amelyen két-két osztrák-magyar, illetve német fótiszt - von Mackensen, von Hötzendorf, von Hindenburg és Kövess tábornokok - látható, Viribus Unitis felirattal. ${ }^{57}$

Kevés térképet ábrázoló levelezőlapot találtunk az áttekintett gyüjteményben, hármat megemlítünk. Egy 1914 augusztusában keltezett a teljes Európa térképét, ${ }^{58}$ egy 1916. júliusi a Galícia-Lublin-Varsó-térséget, ${ }^{59}$ végül a harmadik Tirol déli részének térképét - a mai Dél-Tirolt - ábrázolja. Bal felső sarkában a Die deutsche Grenze treu gerwahrt,/Das ist der Deutsch-tiroler Art felirat van, a bal alsó sarokban hátulnézetből egy rongyos öltözetű alak látható, ülepén Irredenta felirattal, akit egy Tiroler Volksbund feliratú bakancsos láb fenéken billent. A jobb alsó sarok felirata Die Sieben Gemeinden, a hátoldalán, felül a Der Tiroler Volksbund den Truppen in Tirols bergen felirat van, míg alól Es gab kein „Trentino” und wird nie eines geben! ${ }^{100}$ (35. ábra) Azóta már tudjuk, hogy ez bekövetkezett.

Fényképet tartalmazó levelezőlapot szintén keveset találtunk. Ezek közül három példát említünk: kettő a katonák tábori mindennapjaiba - kovácsmúhely és patkolás - engednek betekintést, a harmadik pedig egy osztag csoportképe, két ágyúval. ${ }^{61}$

Utolsó példáinkat a karikatúrák közül válogatva, megemlítünk két, angolokat kifigurázó ilyen ábrázolást. Az egyiken szárazföldön álló, egyenruhás és fegyveres német katonák folytatnak párbeszédet a velük szemben hadihajón ülő, pipázó, borostás, mezítlábas angolokkal:

51 Uo. 47: 330.

52 Uo. 31: 622 .

53 Uo. 39: 78.

54 Uo. 31: 531.

55 Uo. 59: 254.

56 Uo. 24: 146.

57 Uo. 49: 308.

58 Uo. 58: 11.

59 Uo. 48: 454.

60 Uo. 20: 7.

61 Uo. 25: 608-610. 
Angol: Mi nálatok a jelszó?/Német: Wach, - és nálatok?/Angol: Rerwach. ${ }^{62}$ A másik, 1915-ös képeslapon Tirpitz tengernagy fogja a brit oroszlánt, és kérdezi tőle: Who said rats? Wer sprach von Ratten?63 (36. ábra) A karikatúra valószínúleg az Evening Sun lapban jelent meg New Yorkban. Találtunk egy orosz katonákat kifigurázó levelet is 1914 decemberéből, amely egy Gulliver-méretú magyar honvédot ábrázol, amint villával és seprüvel kergeti, sepri az oroszokat. Felirata: Nekünk ezt hozta a Mikulás, villával esszük a muszkát, s mégis van. ${ }^{64}$

A bemutatott példák egy évszázad távlatából őseink életének négy kulcsfontosságú évérôl beszélnek. Amint látható, a háború nem csak karikatúrát, hősiességet, vidám katonacsoportokat jelentett, hanem emberi sorstragédiák, életek összeroppanását is magával hozta. A harcvonalban az élet közel sem volt olyan festői, ahogyan azt gyakran a hadipropaganda ábrázolta, hanem amellett, hogy meg kellett ismerkedni az embertelen életkörülményekkel, az emberi elvadultsággal és a nélkülözéssel, emberek milliói maradtak örökre a harctereken.

\section{PICTURES, DRAWINGS AND OTHER ILLUSTRATIONS ON LETTERS FROM THE WORLD WAR I}

\section{Keywords: World War I, letters, war propaganda, illustrations}

The study presents a topic related to the World War I, topic that links to several other commemorations of the same historical event that started since 2014 all around the world. We used letters from the Collection of letters from the WWI from the former collection of the Archives of the Transylvanian National Museum, today kept in the Cluj County Branch of the Romanian National Archives. Our research focused on the first 91 boxes of the collection, which contain letters sent by soldiers to their relatives from Transylvania (except Banat, Partium and Maramureş). Our goal was to find letters that contain pictures, maps, drawings, songs, caricatures, prayers and pictures from the war. Based on the found material we tried to present certain aspects of the war propaganda and of the lives of the soldiers either from the frontlines, or of those who were left home. Because the WWI was a crucial historical event of our geographical area, it was an interesting challenge to fulfill the research in order to find out more about our ancestors' way of thinking. The war propaganda material showed some exciting pictures and messages which demonstrate that our ancestors were creative in this field.

\section{CĂRŢI POŞTALE, DESENE ŞI ALTE IMAGINI ÎNTRE SCRISORILE DIN PRIMUL RĂZBOI MONDIAL}

\section{Cuvinte-cheie: primul război mondial, scrisori de epocă, propaganda de război, imagini}

Articolul tratează problematica primului război mondial din perspectiva unor scrisori ce conţin fotografii, desene, caricaturi, cântece sau rugăciuni. Pe lângă aceasta am introdus în circuit câteva fotogra-

62 Uo. 47:37.

63 Uo. 48: 154 .

64 Uo. 23: 126. 
fii, hărţi și cărţi poștale ale epocii respective. Materialul arhivistic folosit pentru realizarea acestui articol a fost descoperit în cursul cercetărilor desfăşurate la Serviciul Judeţean Cluj al Arhivelor Naţionale ale României și se află în fondul Colecţia Scrisori din Primul Război Mondial 1914-1918, colecţie aparţinând iniţial Arhivei Muzeului Naţional al Transilvaniei. Am parcurs primele 91 de dosare ale acestui fond, în care au fost grupate scrisori trimise de soldaţi către rudele lor din diferite localităţi ale Transilvaniei. Precizăm că este vorba de localităţi din Transilvania, nu și cele din Banat, Maramureș sau Partium. În același timp este important de reţinut că o parte din materialul descoperit a fost folosit și ca material de propagandă de război de către Puterile Centrale. Am constatat că, în ciuda numărului mare de scrisori din perioada evocată, relativ puţine sunt acelea care au putut fi exploatate din punctul nostru de vedere. Asta deoarece majoritatea scrisorilor sunt scrisori simple, cu tipăriturile standard necesare pe ele. Deoarece prima conflagraţia mondială a adus cu ea schimbări profunde în acest colţ al Europei, am considerat importantă realizarea cercetării de faţă mai ales din curiozitatea de a pătrunde mai profund în modul de gândire al strămoșilor noștri și pentru a vedea într-o lumină mai clară o felie din lumea de acum o sută de ani. 


\section{WELLMANN LÁSZLÓ}

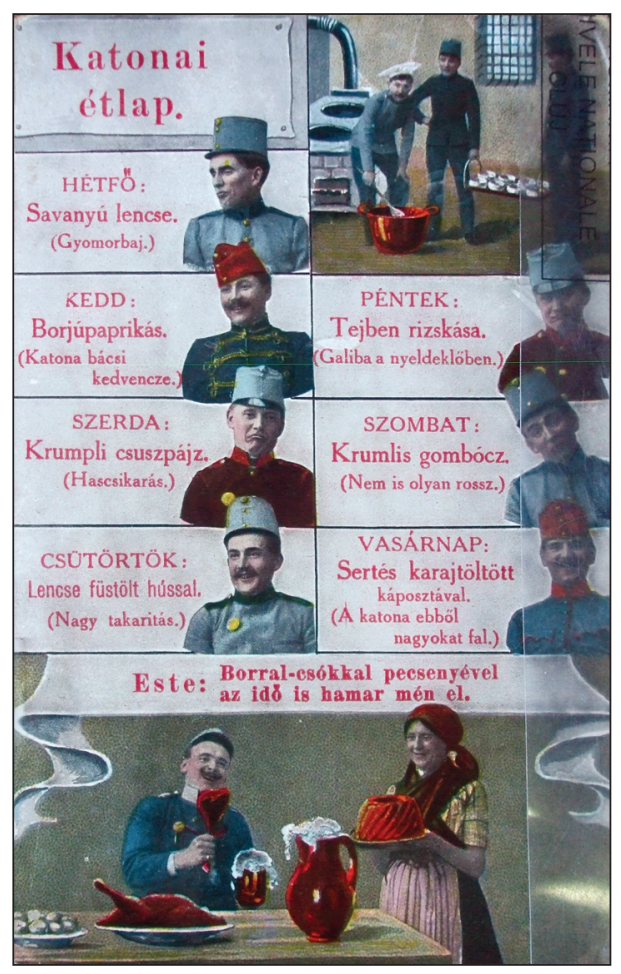

1

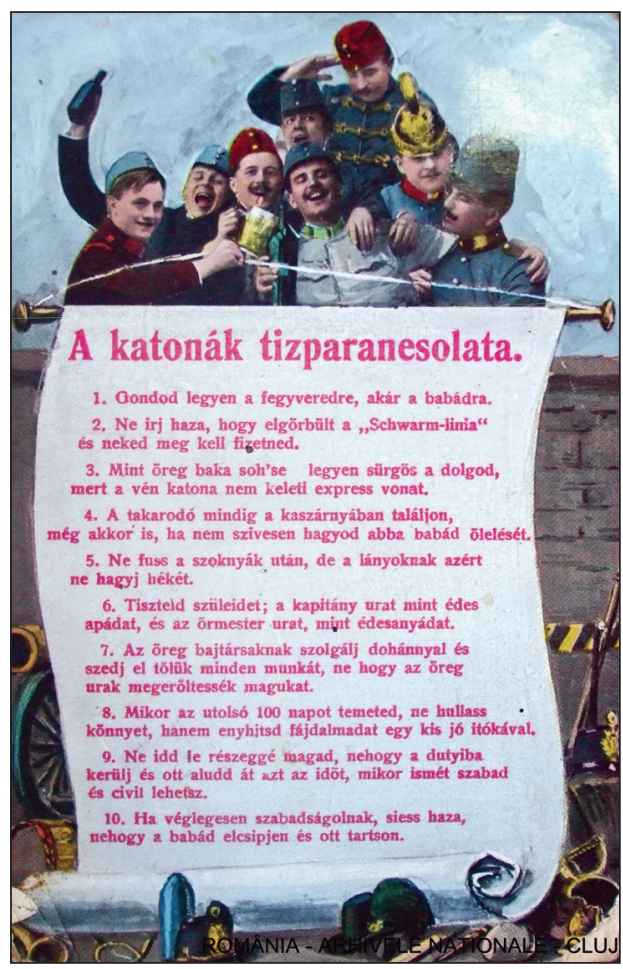

2

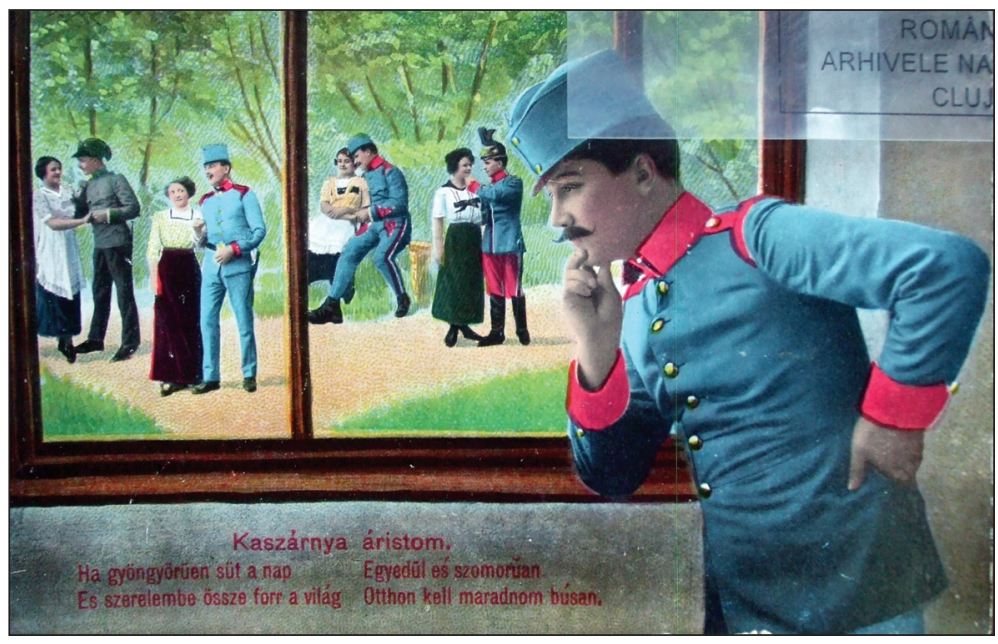




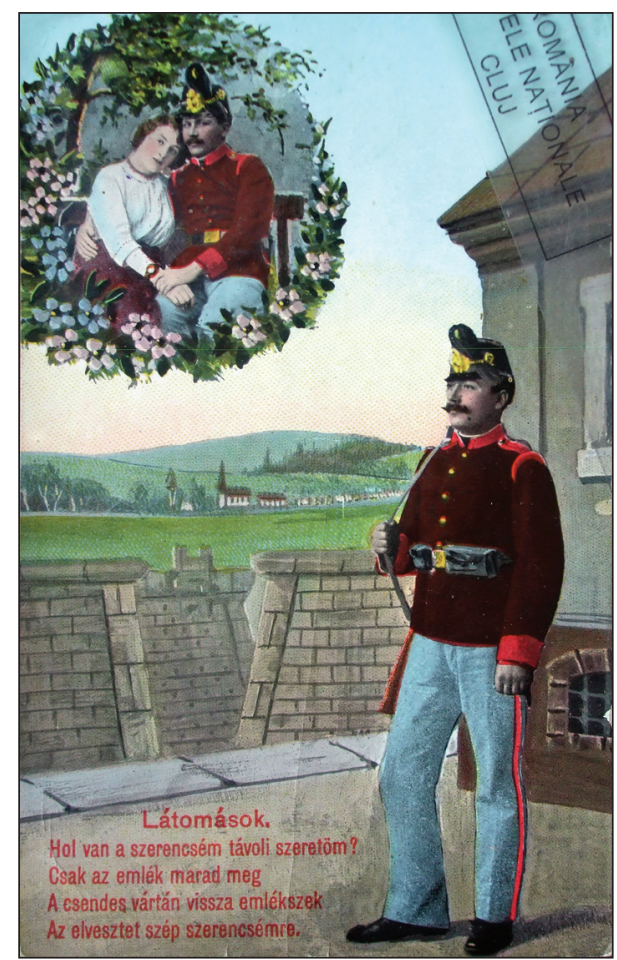

3

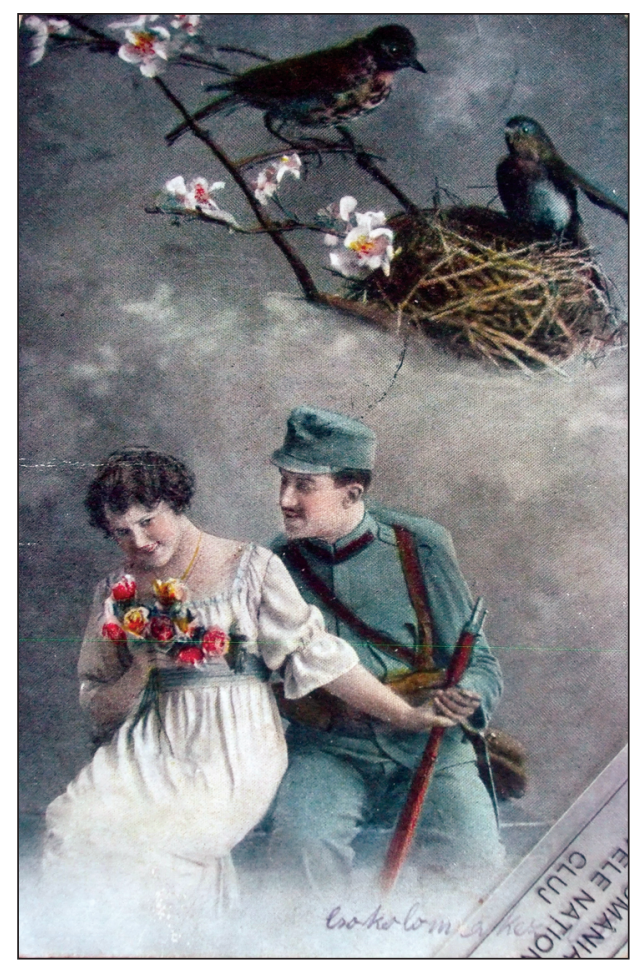

4

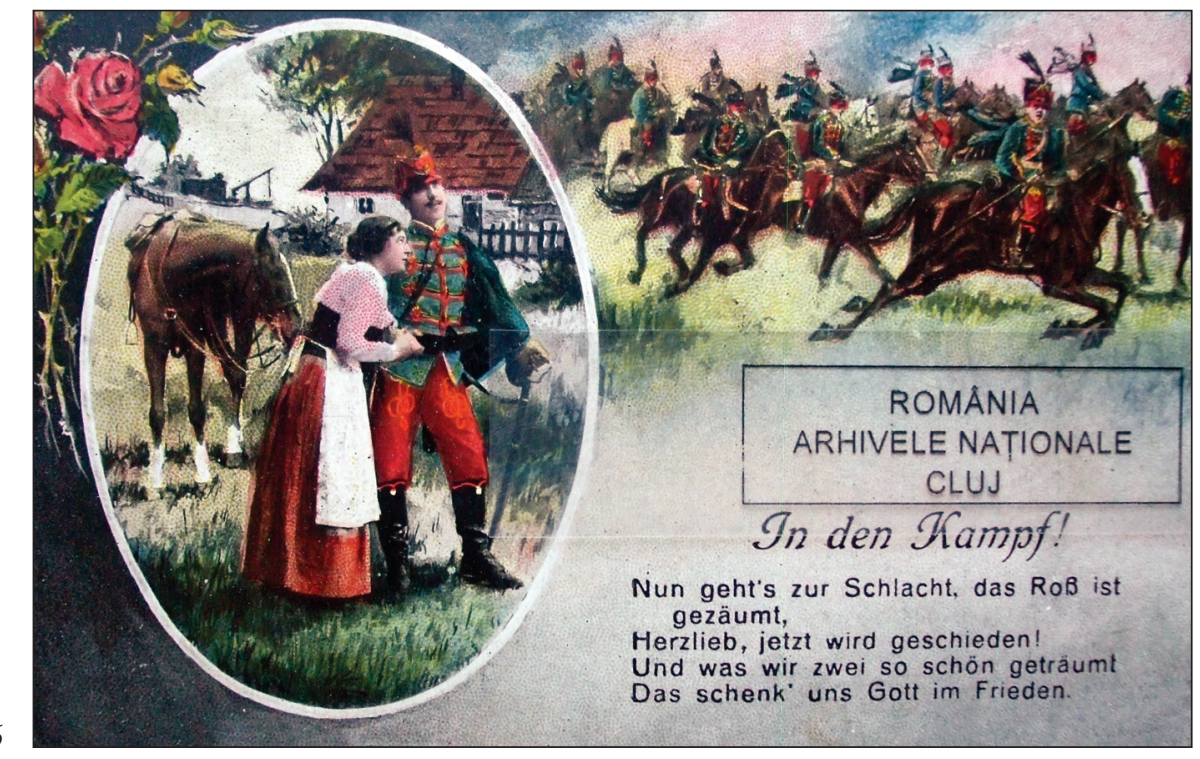


KÉPESLAPOK, RAJZOK ÉS EGYÉB ÁBRÁZOLÁSOK AZ ELSŐ VILÁGHÁBORÚBÓL

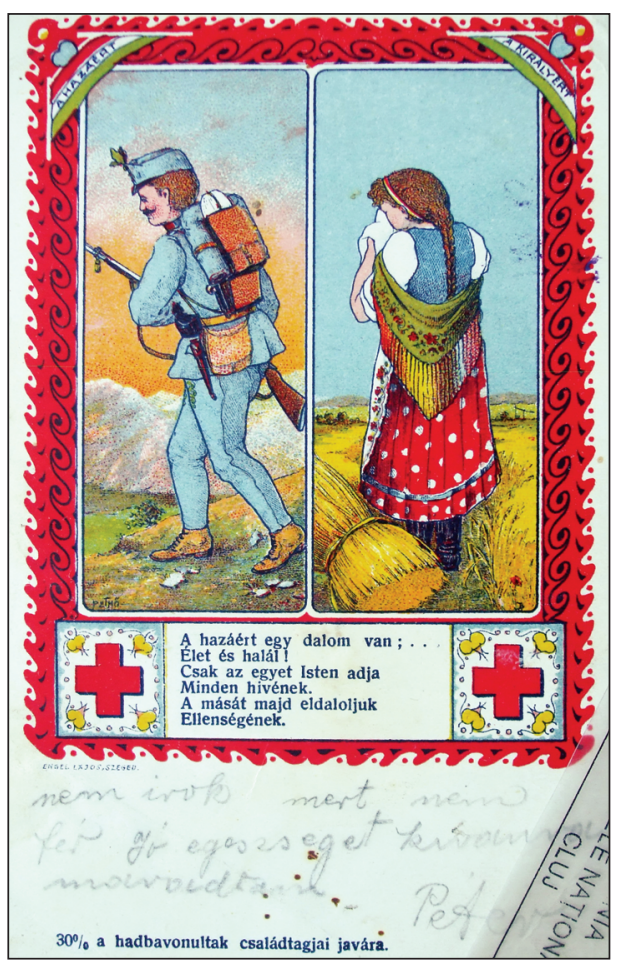

7

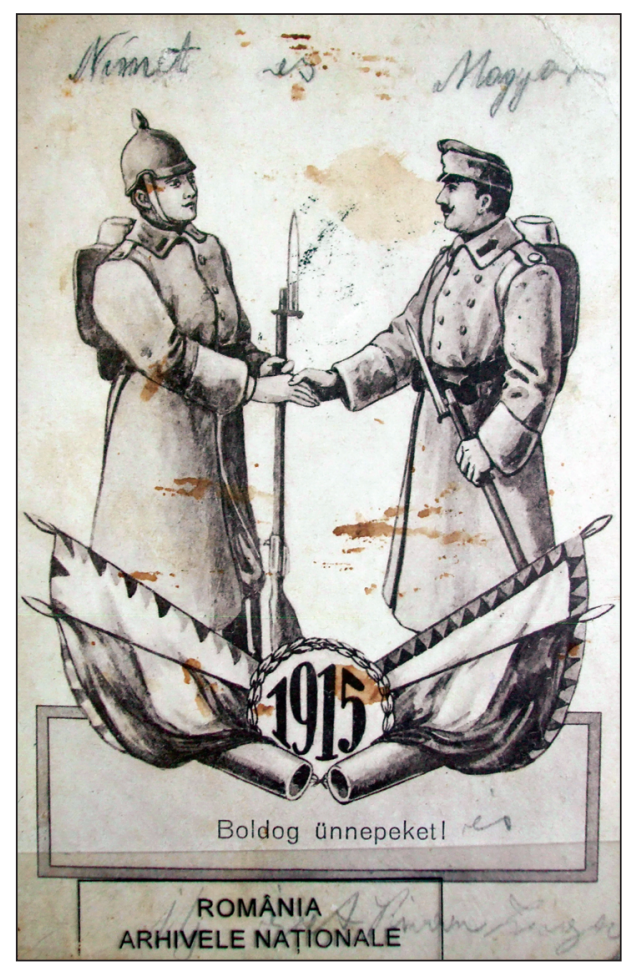

9

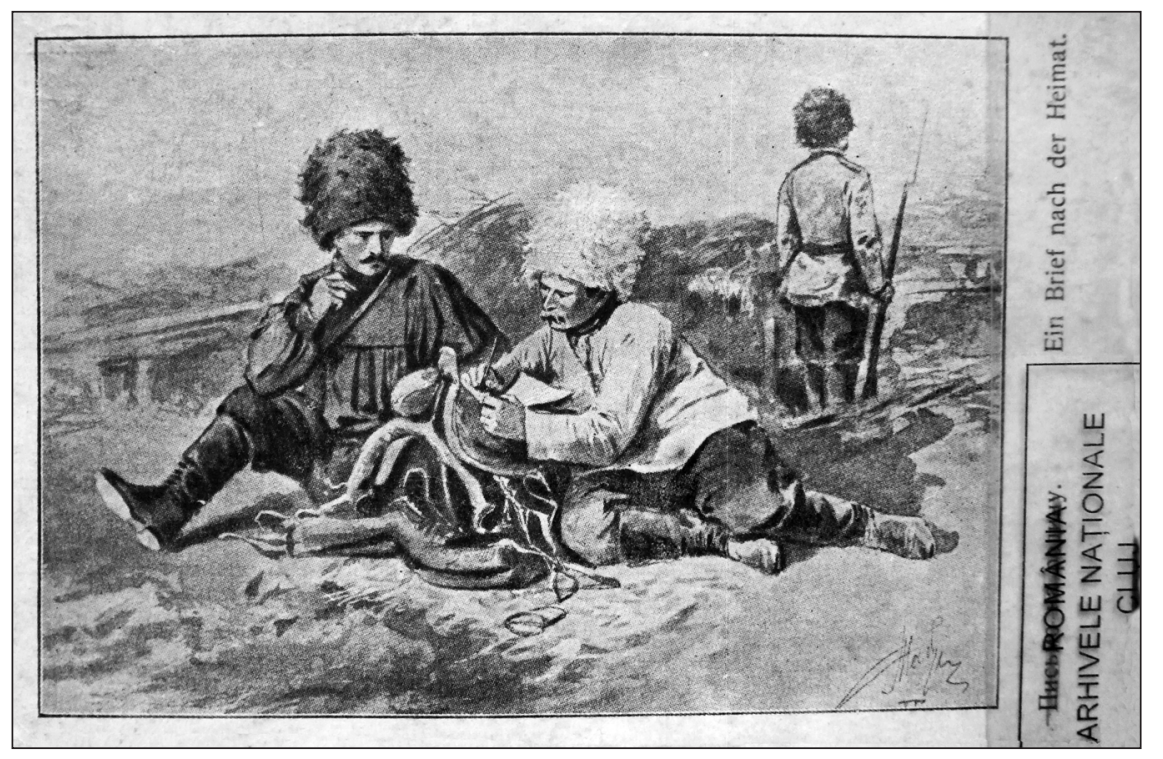




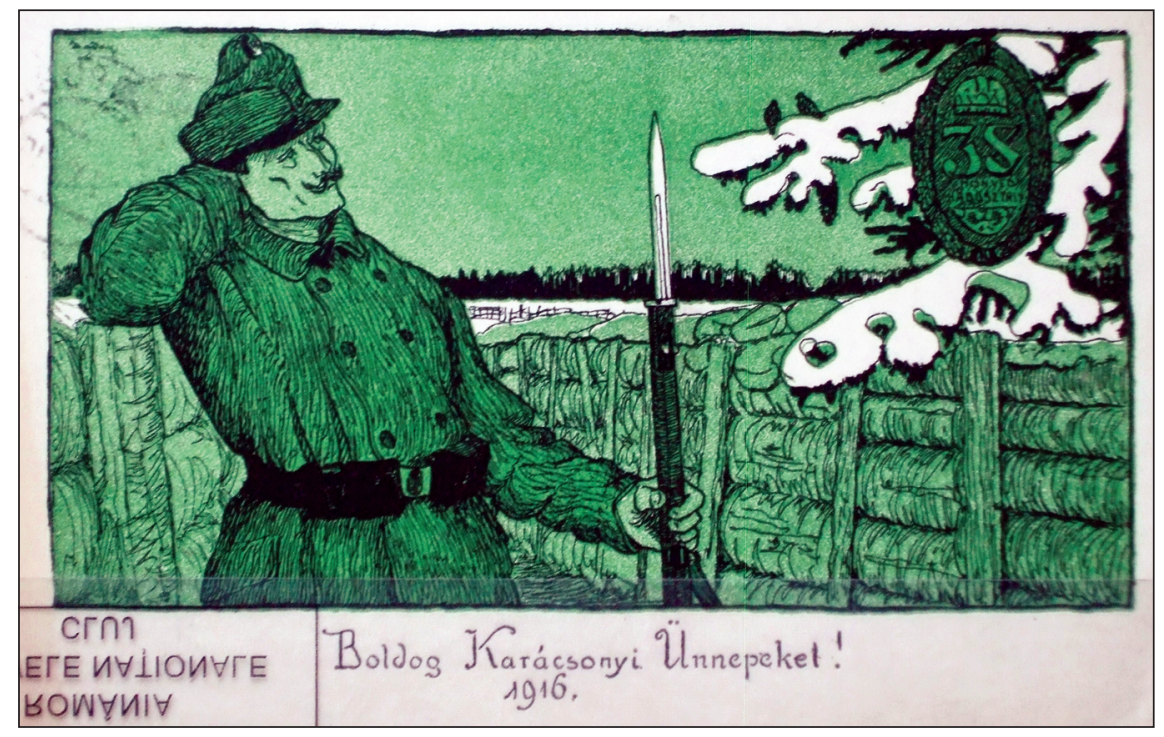

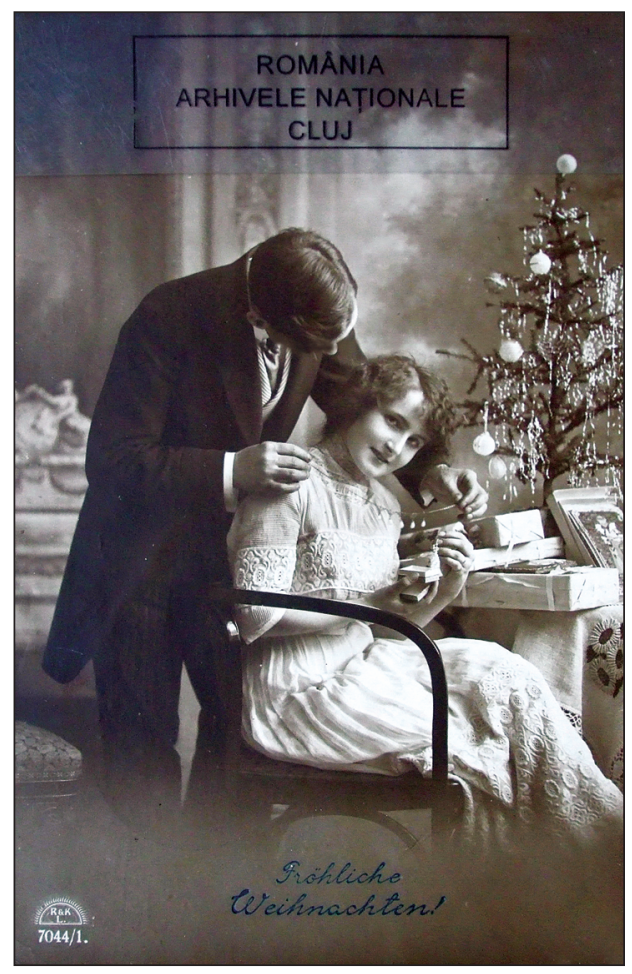

11

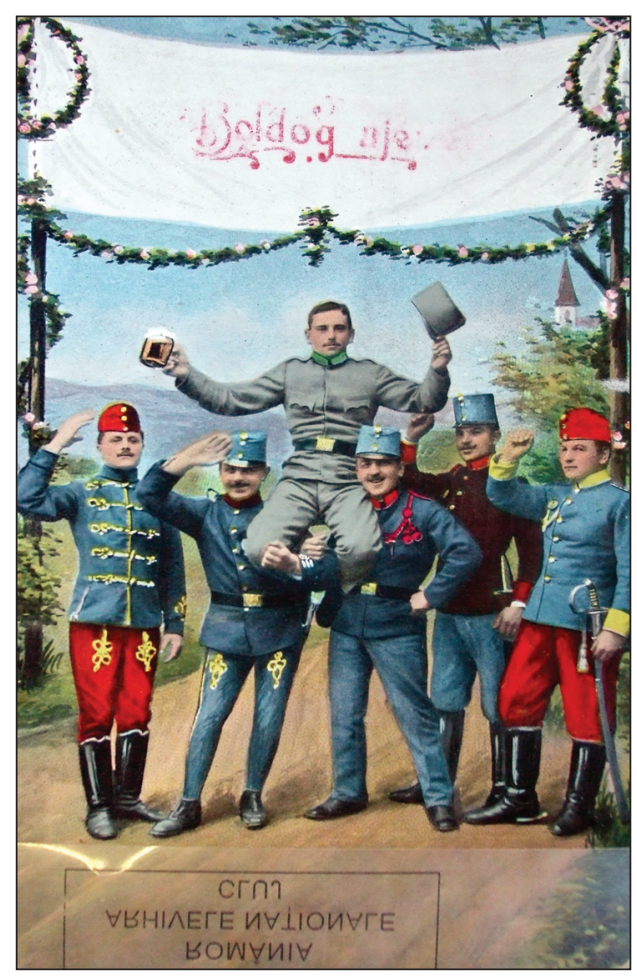

12 
KÉPESLAPOK, RAJZOK ÉS EGYÉB ÁBRÁZOLÁSOK AZ ELSŐ VILÁGHÁBORÚBÓL

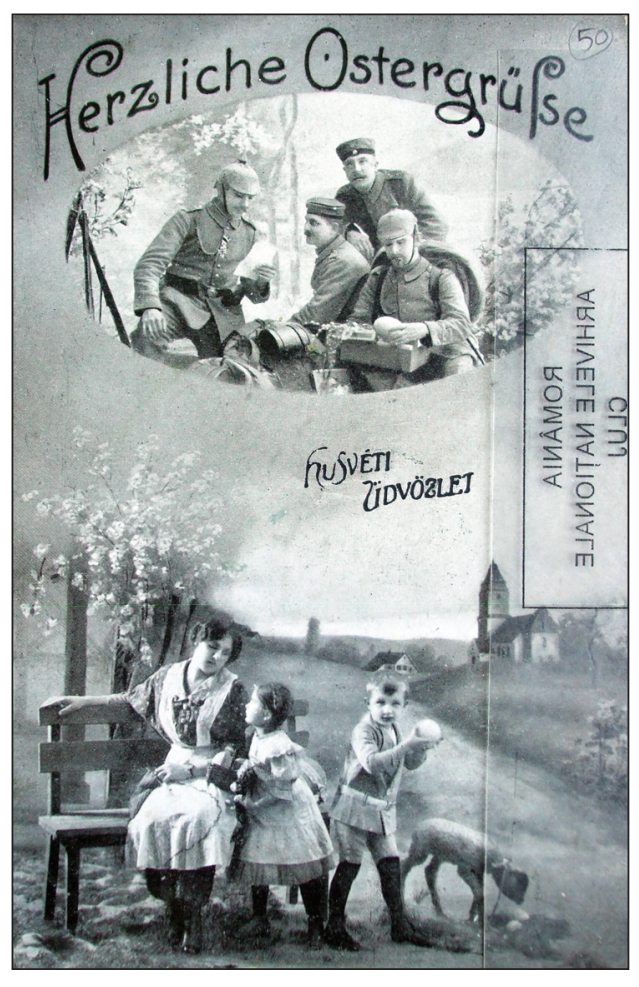

13

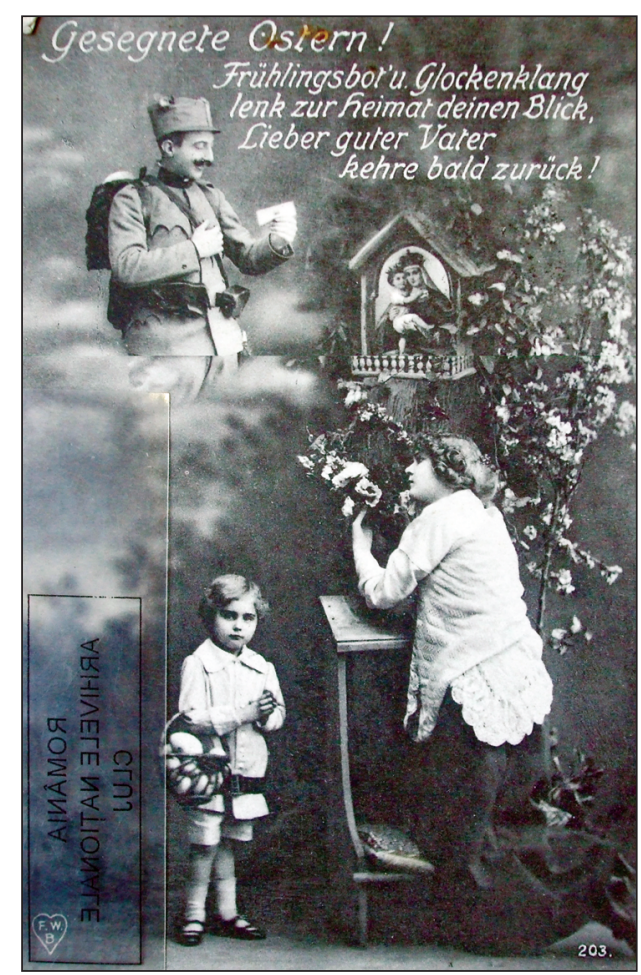

14

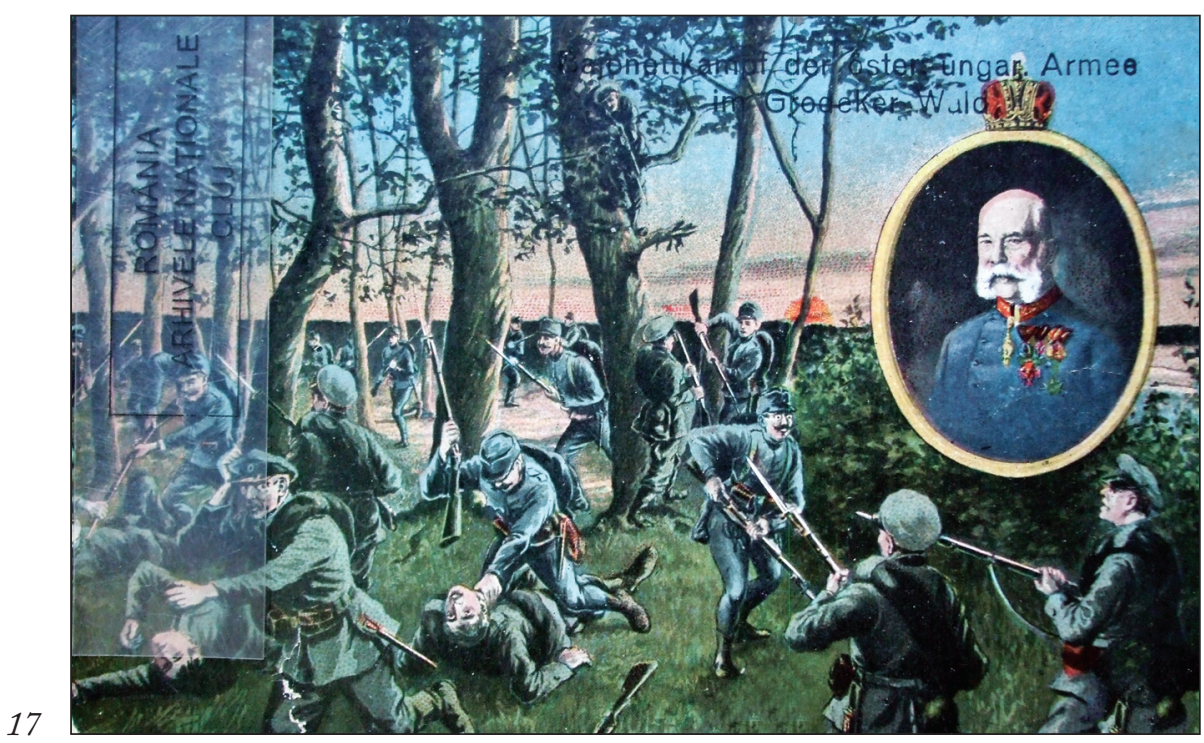




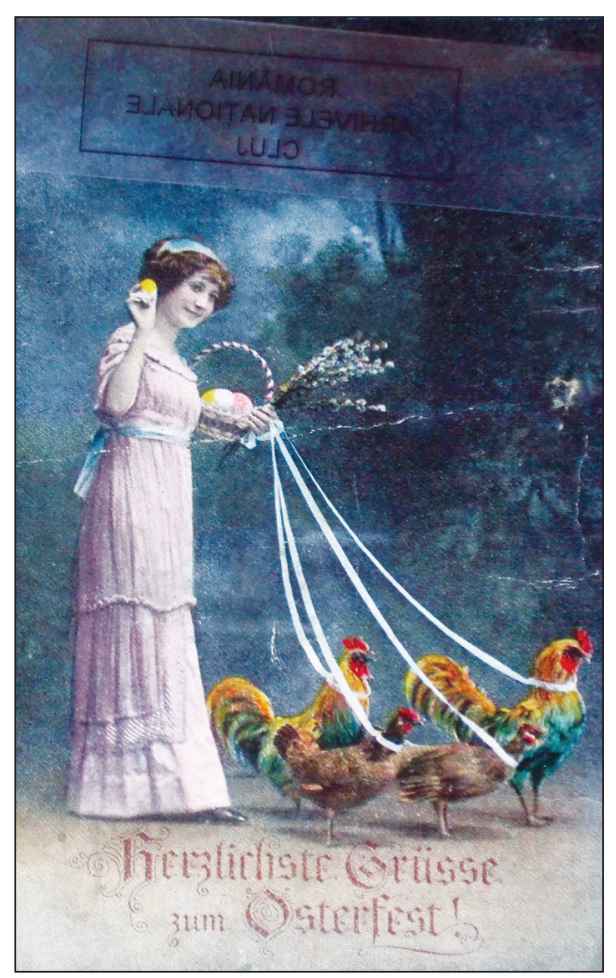

15

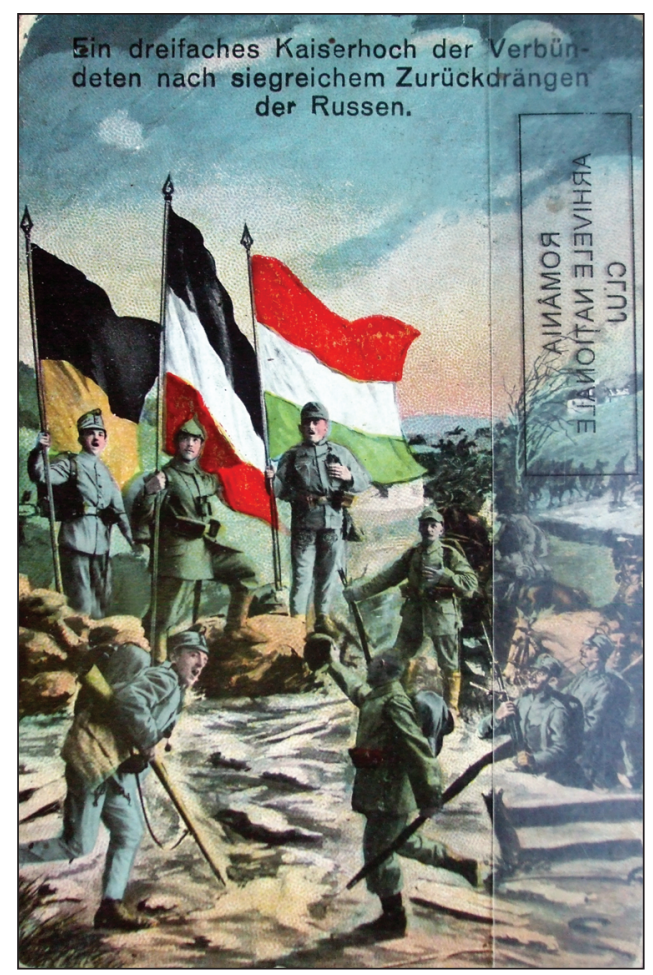

16

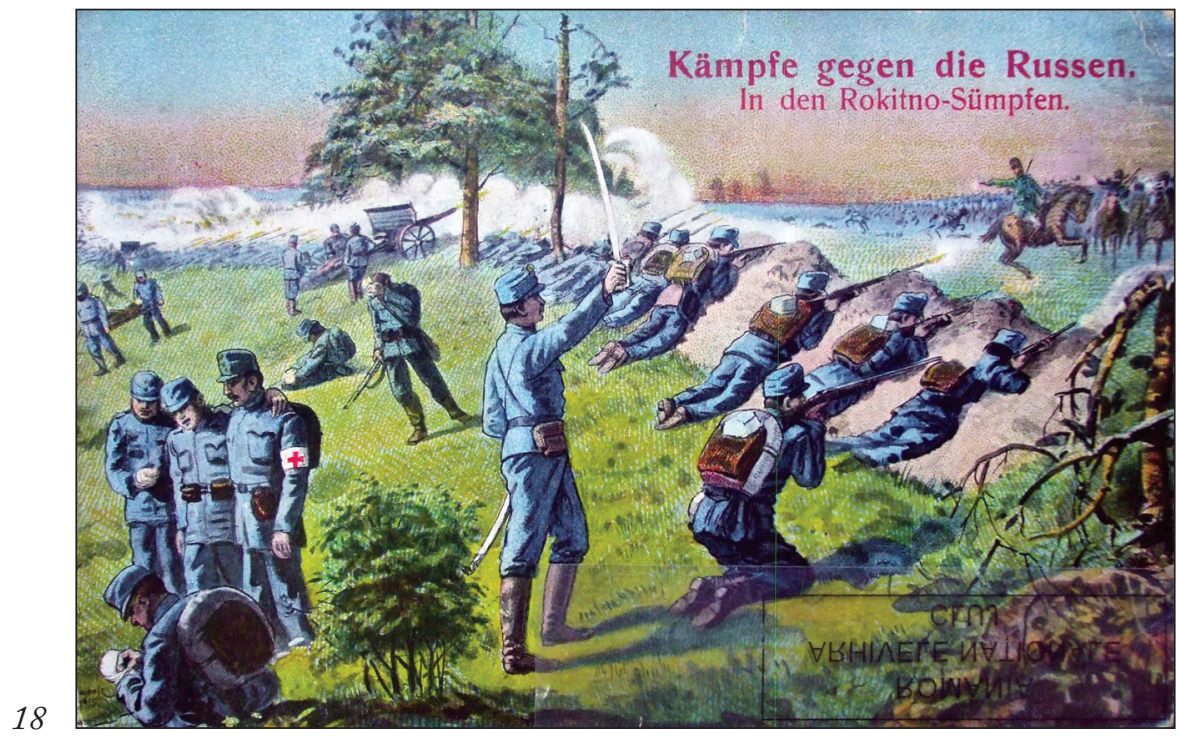


KÉPESLAPOK, RAJZOK ÉS EGYÉB ÁBRÁZOLÁSOK AZ ELSŐ VILÁGHÁBORÚBÓL

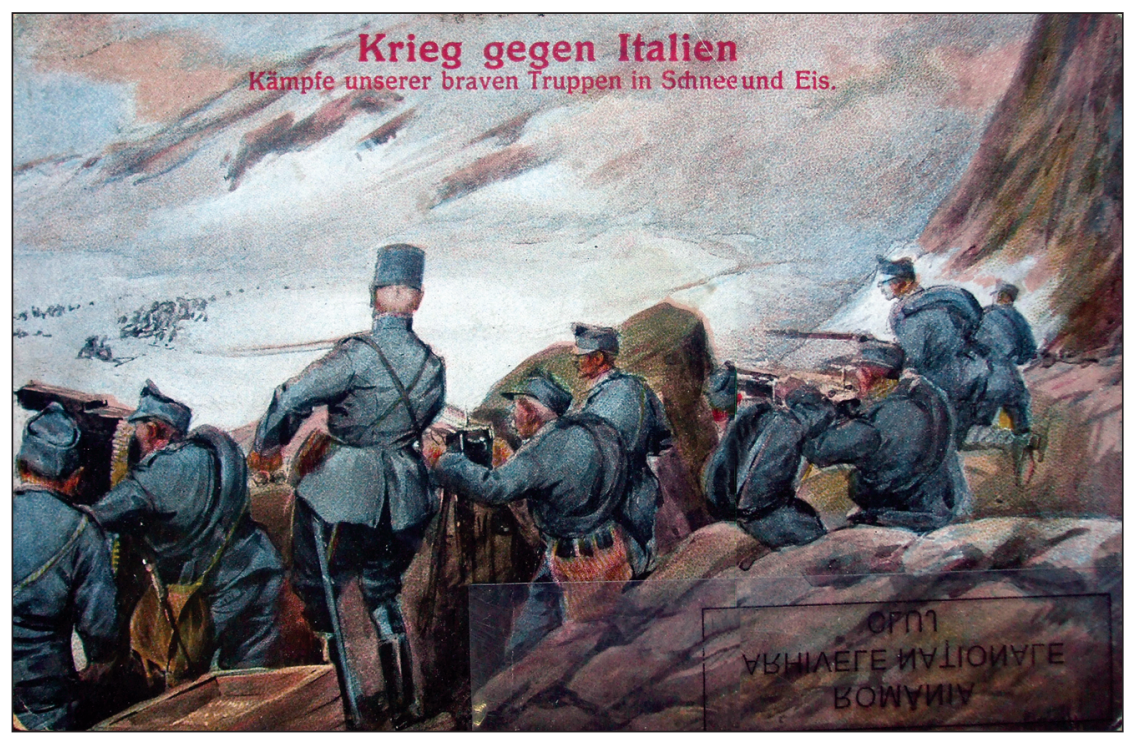

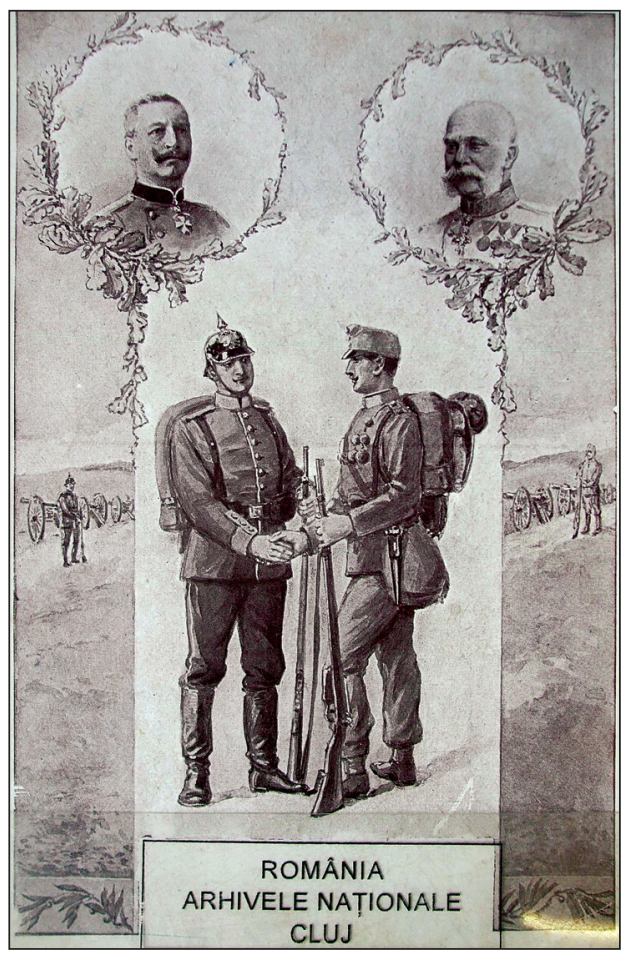

20

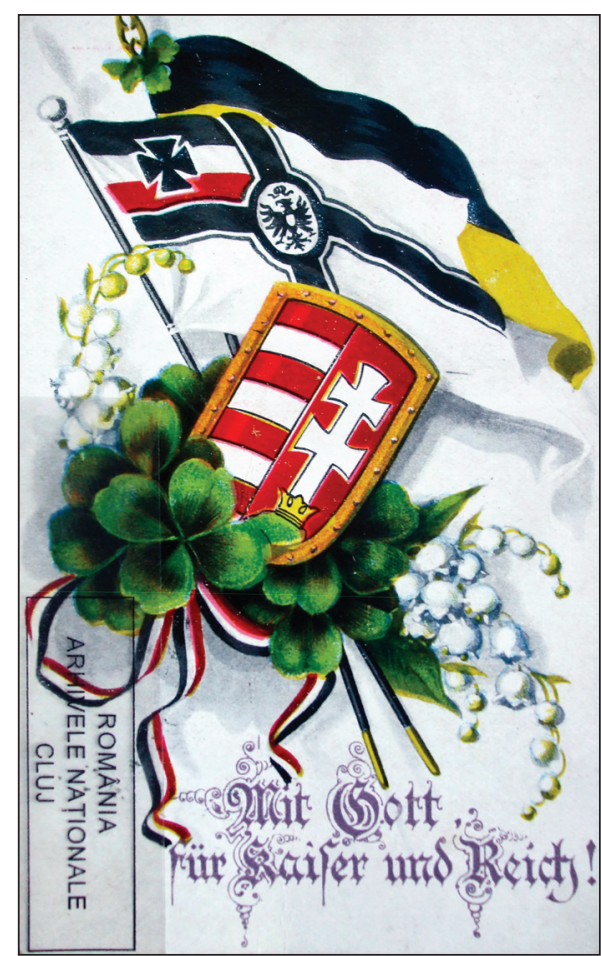

23 

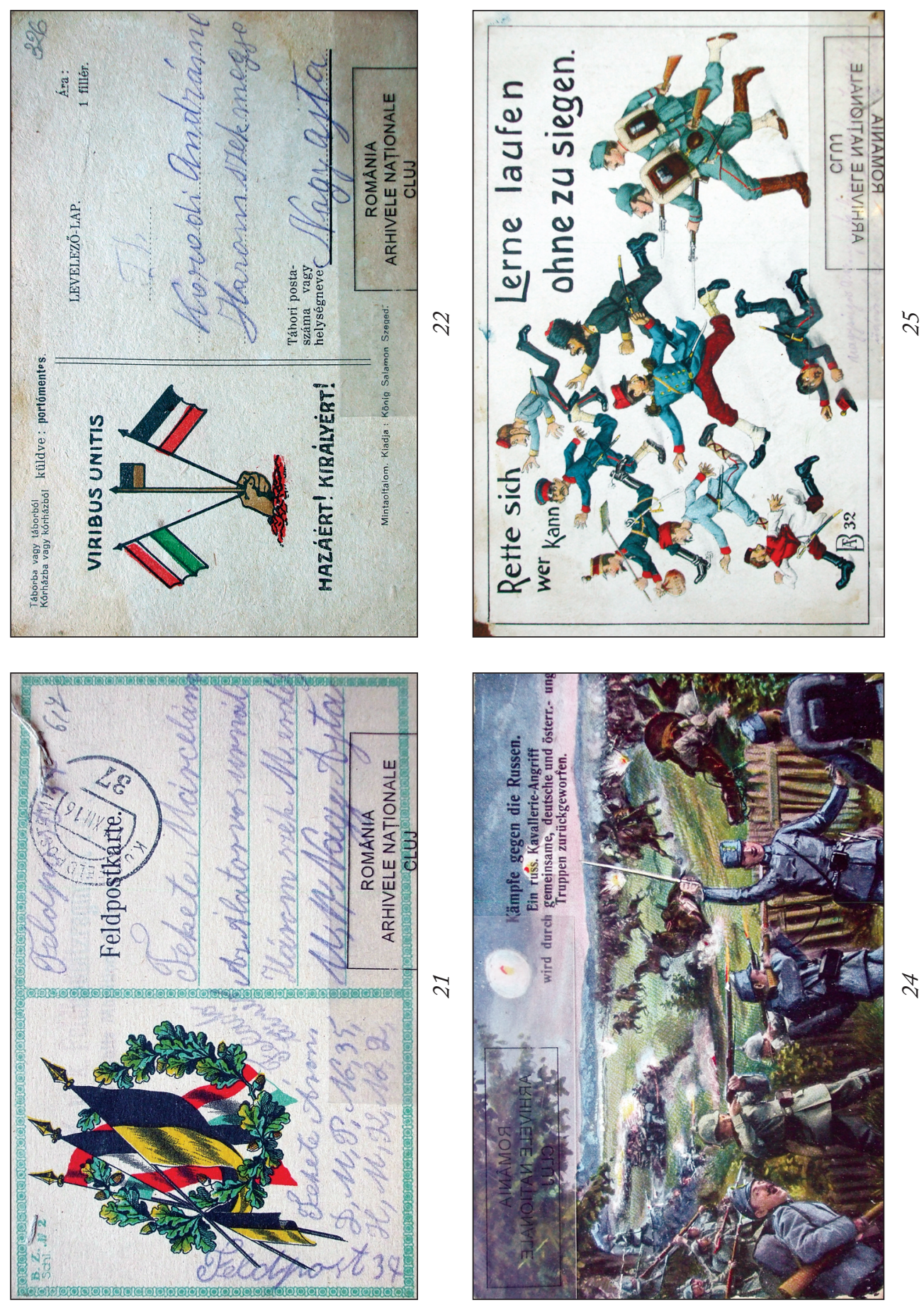
KÉPESLAPOK, RAJZOK ÉS EGYÉB ÁBRÁZOLÁSOK AZ ELSŐ VILÁGHÁBORÚBÓL
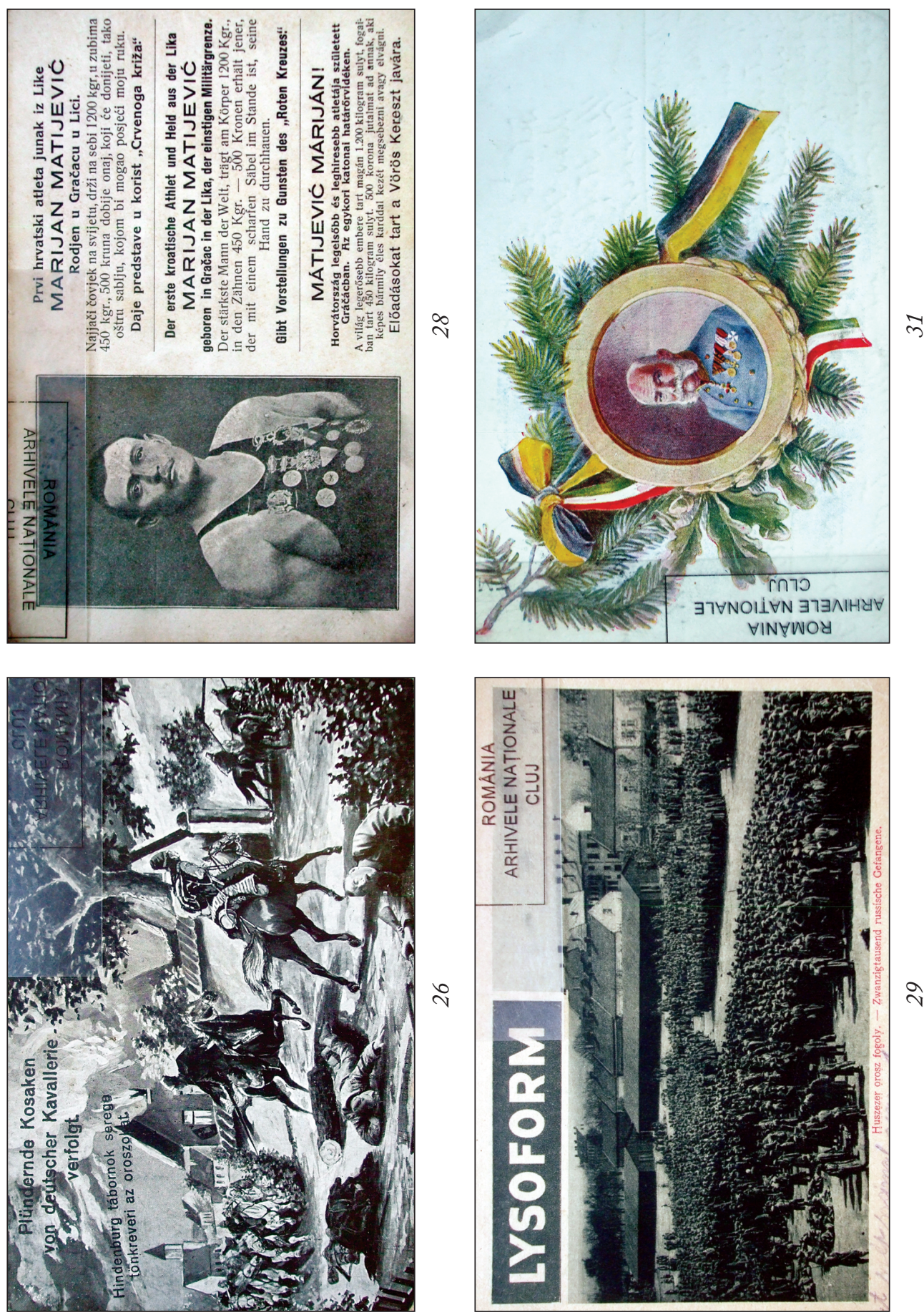


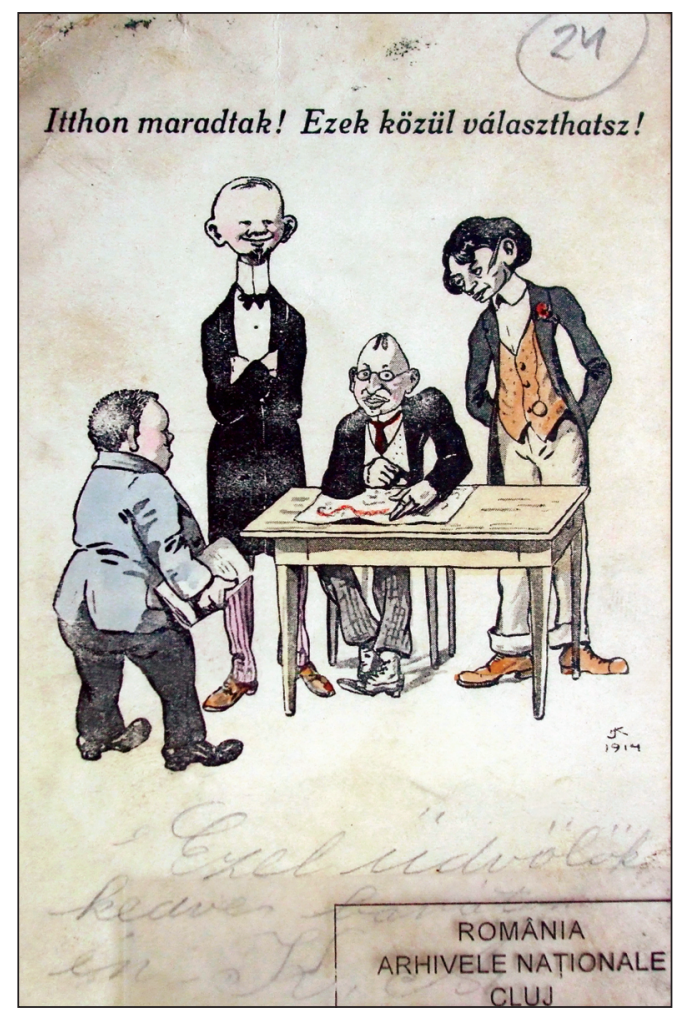

27

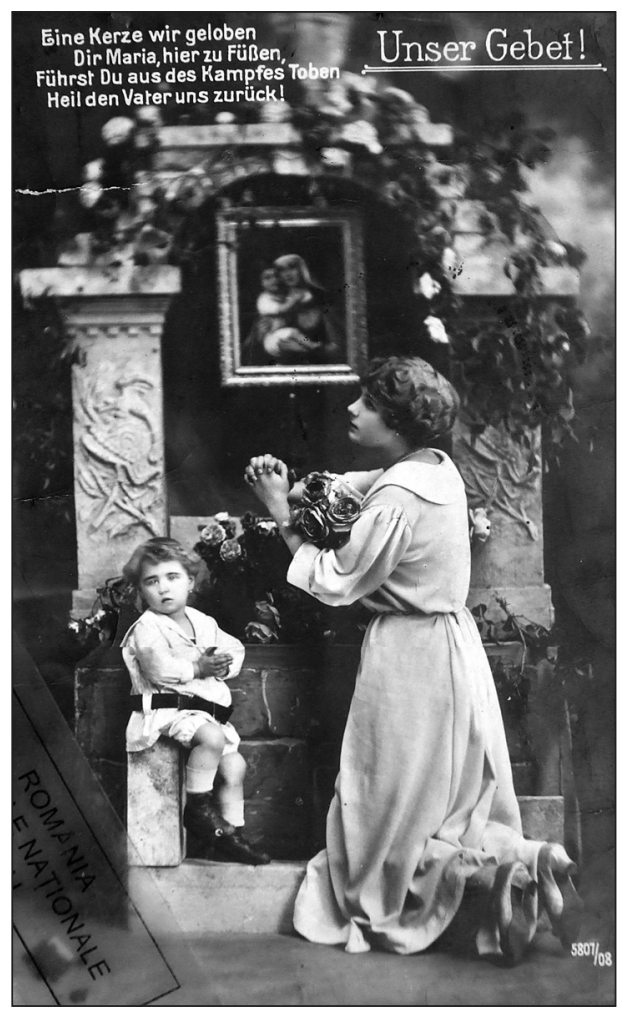

30

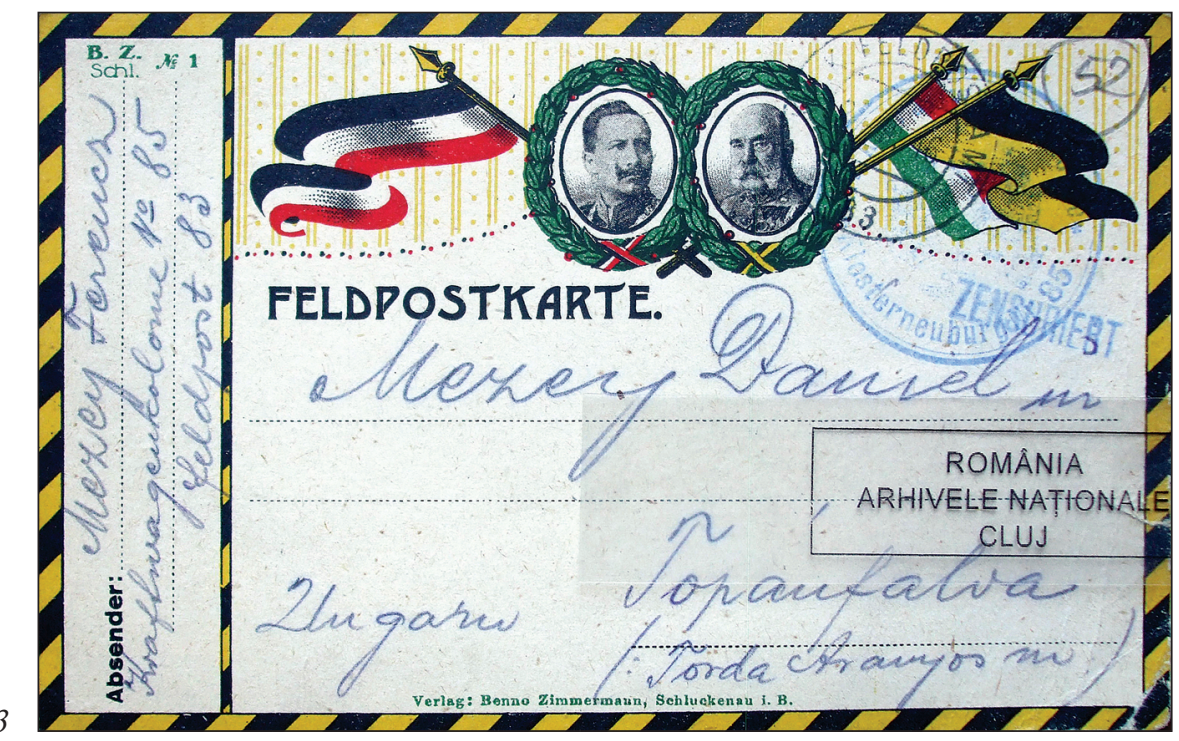


KÉPESLAPOK, RAJZOK ÉS EGYÉB ÁBRÁZOLÁSOK AZ ELSŐ VILÁGHÁBORÚBÓL
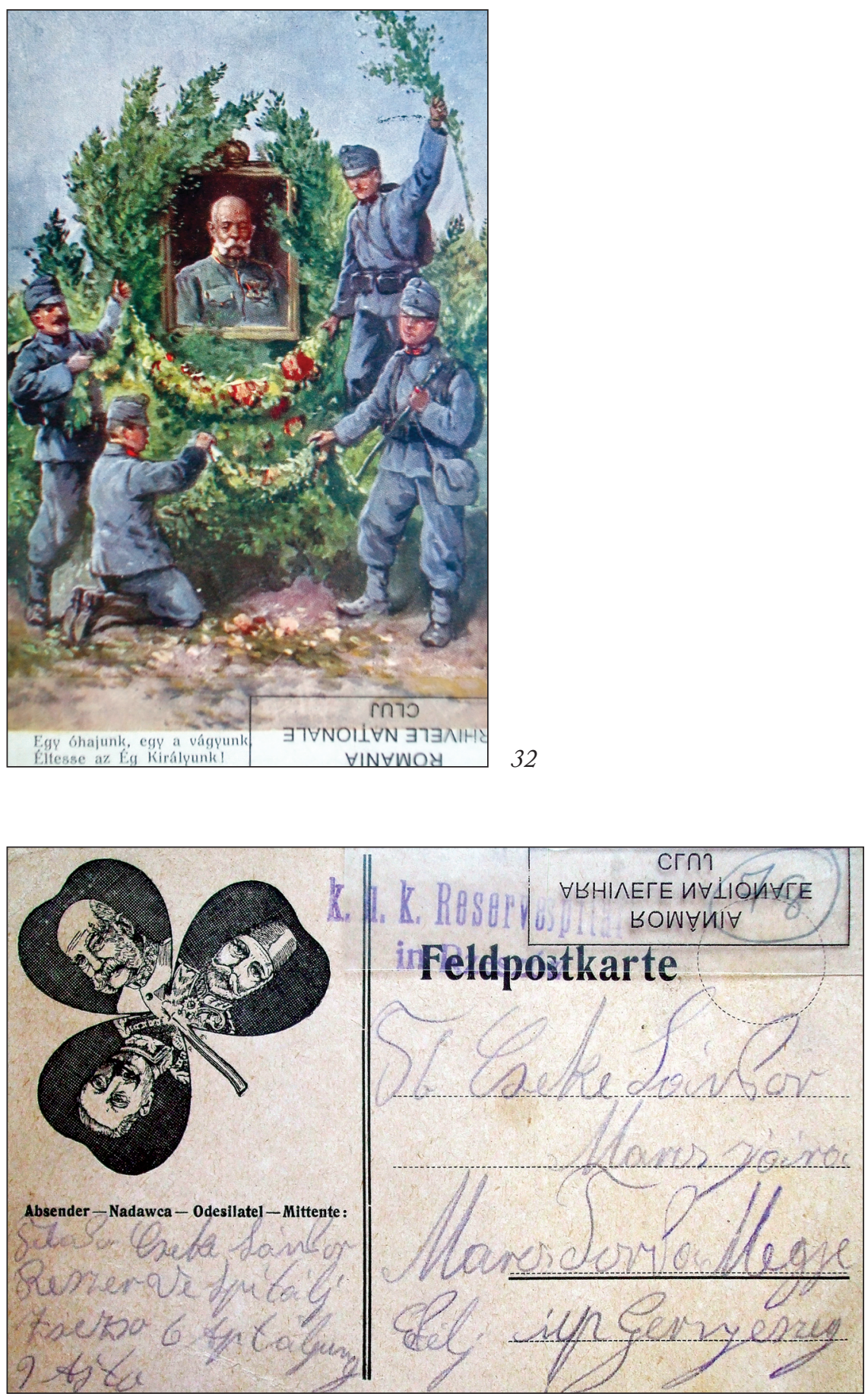

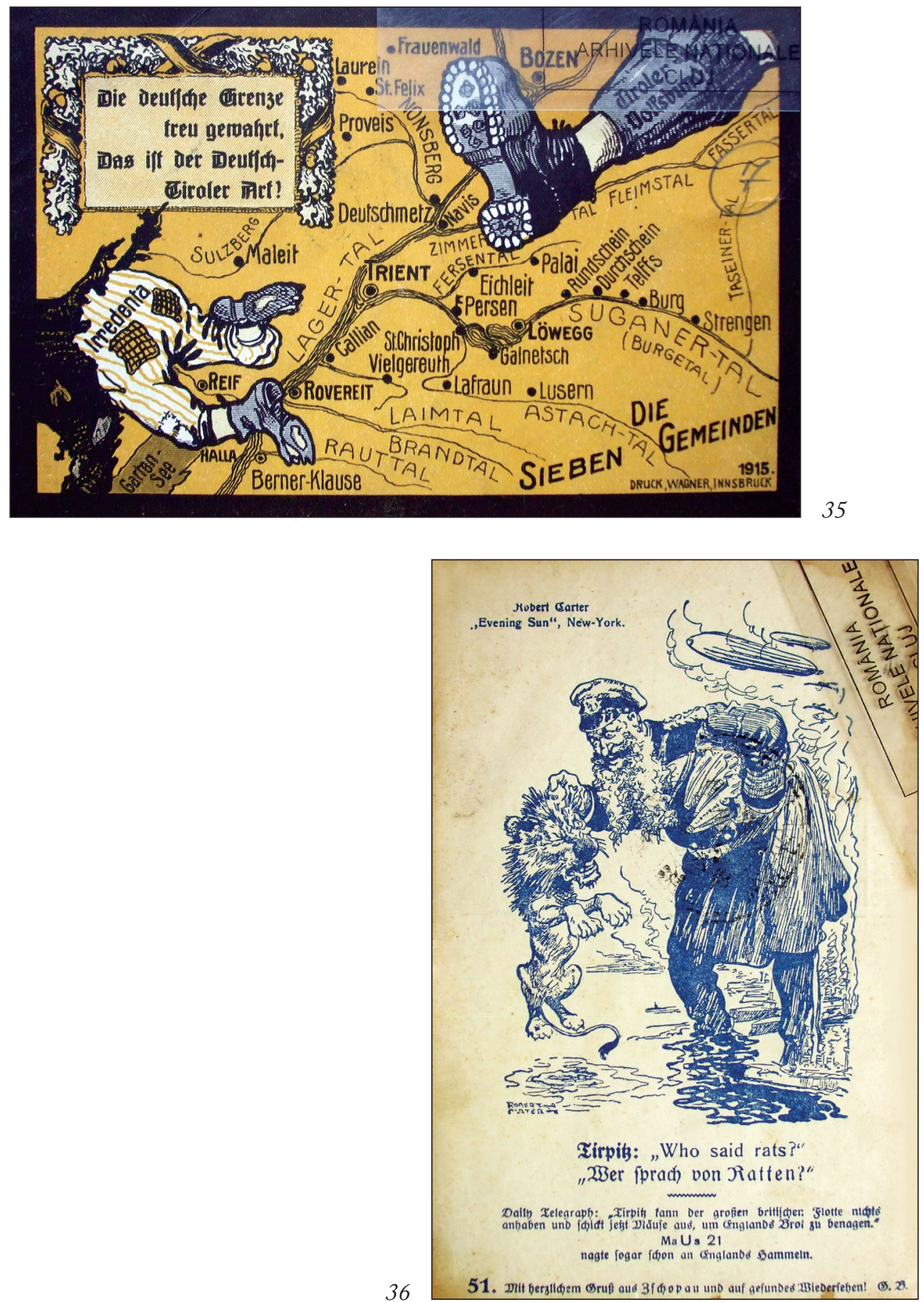